\title{
The Effects of Postpartum Education in Primipara Mothers on Their Readiness for Hospital Discharge and Maternal Self-confidence
}

\author{
Primipar Annelere Verilen Postpartum Eğitimin Taburculuğa Hazır Oluşluk \\ Düzeyi ile Annelik Özgüvenine Etkisi
}

\author{
Betül Sönmez ${ }^{1}$, (1) Rojjin Mamuk² \\ ${ }^{1}$ Dr. Burhan Nalbantoğlu State Hospital, Nicosia, North Cyprus \\ 2Eastern Mediterranean University, Faculty of Sciences, Department of Nursing, Famagusta, North Cyprus
}

\begin{abstract}
Objective: The postpartum period is one of the most critical periods of a woman. Thus, this study aimed to determine the effect of the postpartum education that is provided to mothers on the readiness for hospital discharge and maternal self-confidence.

Methods: This quasi-experimental study, with a non-random post-test control group, included all postpartum mothers who are hospitalized in a state hospital, including 102 primipara postpartum mothers (50 patients for the experimental group and 52 for the control group). Data were collected using a personal information form, Pharis self-confidence scale (PSCS), and Readiness for Hospital Discharge Scale-New Mother form (RHD-NMF). No intervention was made to the control group except for data collection. The experimental group took structured postpartum and neonatal care education and data were collected.

Results: The study showed that the experimental group's PSCS scores, the mean RHD-NMF total scores, and the RHD-NMF personal status, knowledge, and ability subscales were significantly higher than the control group $(p<0.05)$. Furthermore, a significant positive correlation was determined between the two scales $(p<0.05)$

Conclusion: This study revealed that postpartum education supports mothers' readiness for hospital discharge and maternal self-confidence. Therefore, it should be routinely practiced in hospitals.
\end{abstract}

Keywords: Education, postpartum period, readiness for hospital discharge, self-confidence, women

\section{Öz}

Amaç: Doğum sonu dönem kadın yaşamının en kritik evrelerinden biridir. Bu çalışmada da doğum sonrası annelere verilen postpartum eğitimin taburculuğa hazır oluşluk düzeyi ile annelik özgüvenine etkisini belirlemek amaçlandı.

Gereç ve Yöntem: Çalışma yarı deneysel randomize olmayan gruplarda son test kontrol gruplu olarak tasarlandı. Çalışmanın evrenini bir devlet hastanesinde yatmakta olan lohusaların tamamı, örneklemini ise örneklem seçim kriterlerine uyan 102 (Deney 50/Kontrol 52) primipar lohusa oluşturdu. Verilerin toplanması aşamasında kişisel bilgi formu, Hastane Taburculuğuna Hazır Oluşluk Ölçeği-Yeni Doğum Yapmış Anne formu (HTHÖ-YDAF), pharis özgüven ölçeği (PÖÖ) kullanıldı. Kontrol grubuna veri toplama formlarının uygulanması haricinde herhangi bir müdahalede bulunulmadı. Deney grubuna ise yapılandırıımış Lohusalık ve Yenidoğan Bakımı Eğitimi verildikten sonra veri toplama araçları uygulandı.

Bulgular: Çalışmada PÖÖ puanları, HTHÖ-YDAF'nin toplam ortalama ölçek puanı ile HTHÖ-YDAF'nin kişisel durum, bilgi ve yetenek alt boyutlarının deney grubu; HTHÖ-YDAF'nin beklenen destek alt boyutunun ise kontrol grubu lehine anlamlı fark gösterdiği saptandı ( $<<0,05)$. Ayrıca iki ölçek puanları arasında istatistiksel olarak anlamlı ve pozitif yönde korelasyonlar olduğu tespit edildi $(p<0,05)$.

Sonuç: Bu çalışma taburculuk öncesi verilen postpartum eğitimin, lohusaların taburculuğa hazır oluşluk düzeyi ile annelik özgüvenini olumlu yönde desteklediği ve bu nedenle hastanelerde rutin olarak uygulanması gerektiğini göstermektedir.

Anahtar Kelimeler: Eğitim, doğum sonu dönem, taburculuğa hazır oluşluk, kadınlar, özgüven

Address for Correspondence: Rojjin Mamuk, Eastern Mediterranean University, Faculty of Sciences, Department of Nursing, Famagusta, North Cyprus

Phone: +90 3926303939 E-mail: rojinmamuk@gmail.com ORCID ID: orcid.org/0000-0003-3612-2010

Cite as: Sönmez B, Mamuk R. The Effects of Postpartum Education in Primipara Mothers on their Readiness for Hospital Discharge and Maternal Self-confidence. Med J Bakirkoy 2021;17:286-292

Received: 07.01.2021

Accepted: 19.11.2021 


\section{INTRODUCTION}

The postpartum period is a critical term that involves several physical and psychosocial changes, as well as new roles and responsibilities. Thus, protecting and increasing both the mother's and the baby's health is critical $(1,2)$. Today, most deliveries occur in the hospitals; however, postpartum care duration is very limited due to early discharge $(3,4)$. The professional healthcare that is provided to families in the hospitals in the countries with postpartum home care and follow-up services is retained at home too, which makes postpartum early discharge advantageous for the family and health economy $(3,5)$. However, this is not the case for countries that have no or insufficient prenatal training and consultancy services and postpartum home care $(6,7)$.

Parental attitudes and behaviors are factors that affect the healthy growth and development of a baby $(8,9)$. The parental self-confidence level is known to affect the attitudes and behaviors of parents (10-12). Nevertheless, physical changes during the early postpartum period, such as breastfeeding, bleeding, pain, and medical interventions if any, adaptation to motherhood, and parental self-confidence processes, occur $(13,14)$. Studies showed a negative correlation between maternal self-confidence and stress, anxiety, and postpartum depression based on physical changes $(15,16)$. Particularly, primipara, young mothers, mothers in the risky postpartum period, and those with premature babies need more support for information on self-care and baby-care $(17,18)$. Therefore, training is organized that considers all mothers' skills, self-confidence, and support elements, especially those under risk information on self-care and baby-care $(19,20)$.

Studies indicated that postpartum education and information affect mothers' readiness for hospital discharge (21-23) and maternal self-confidence (24-26). However, no study has searched for the relationship between readiness for hospital discharge after planned postpartum education and maternal self-confidence.

\section{Aim}

This study aimed to determine the effect of the postpartum education that is provided to mothers on the readiness for hospital discharge and maternal self-confidence.

\section{Research Hypotheses}

$\mathrm{H}_{1}$ : A difference is found between the scores of mothers who received and those who did not receive postpartum and neonatal care education from the readiness for hospital discharge scale-new mother form (RHD-NMF).
$\mathrm{H}_{2}$ : A difference is found between the scores of mothers who received and those who did not receive postpartum and neonatal care education from the Pharis self-confidence scale (PSCS).

$\mathrm{H}_{3}$ : A correlation is found between the scores of RHD-NMF and the PSCS.

\section{METHODS}

\section{Study Design}

This is a quasi-experimental study with a non-random posttest control group.

\section{Participants and Setting}

The study was conducted between May 1 and November 1 , 2019, in a gynecology clinic in a public hospital in Northern Cyprus. As hospital protocol, hospital discharge was $24 \mathrm{~h}$ for non-risky postpartum and neonatal vaginal deliveries and $72 \mathrm{~h}$ for cesarean (C-section) deliveries. The hospital did not offer structured education for postpartum and neonatal care during pregnancy or postpartum period. The population of the study consisted of all postpartum mothers who are hospitalized in the gynecology clinics between the abovementioned dates. Its impact size was calculated as $d=0.75$, taking the total mean score that is obtained in the study of Burucu and Akın (21) as reference. With help of G*Power 3.1.9.2 software, the sample size that is needed for $95 \%$ power was 82 in total ( 41 in the experimental group and 41 in the control group). Considering potential drop-outs, the study was completed with 102 postpartum mothers (50 in the experimental and 50 in the control group). Additionally, the sampling criteria included primipara, postpartum mothers, over 18 years old, with Turkish literacy, no health problems of themselves or their babies, and are ready for discharge.

\section{Data Collection Tools}

The data were collected using personal information form, RHD-NMF, and PSCS.

\section{Personal Information Form}

The questionnaire was developed by the researcher, which included 18 questions regarding the mothers' sociodemographic, obstetric, and postpartum characteristics $(21,27,28)$.

\section{RHD-NMF}

The validity and reliability study of the scale was developed to determine the postpartum mothers' early readiness for hospital discharge as conducted by Weiss et al. (29) in 2006 and Weiss and Piacentine (30). The validity and reliability of 
the Turkish version were done by Akın and Şahingeri (27) This scale consisted of 4 subscales and 23 items in total. The first item was about the mother's readiness for planned discharge that is answered with a binary response (dichotomous) (yes/ no) and was not included in the scoring. Other items were scored "0" to "10" by Likert-type scoring (27).

Items 2-9 were included in the first subscale (personal status). The third and sixth items were reverse scored. The second subscale (Knowledge) included items 1016, the third subscale (Ability) included items 17-19, and the fourth subscale (expected support) included items 20-23. The lowest obtainable score was " 0 " the highest was "220." A higher score indicated higher readiness for hospital discharge, whereas lower scores indicated less readiness for hospital discharge. The scale was designed for hospital discharge. The Cronbach's Alpha value was 0.70 for its Turkish version (27). This value was found at 0.89 in the current study.

\section{PSCS}

The Turkish validity and reliability study of this scale that evaluates the self-confidence feelings of parents on daily maternal care was performed by Çalışır (28) with the reliability coefficient between 0.86 and 0.85 . The PSCS is a five point-scale that consists of 13 items. Each baby-care item was scaled from 1 to 5 (none, few, partially, mostly, and completely). The lowest obtainable score from the scale was 13 and the highest was 65. A higher score indicated an increased self-confidence of parents about baby-care (28). The Cronbach's Alpha value was 0.94 in this study.

\section{Education Plan Used in the Study}

The education was planned at least postpartum $6 \mathrm{~h}$ for vaginal delivery and $24 \mathrm{~h}$ for $\mathrm{C}$-section post-operation and takes approximately $60 \mathrm{~min}$ when mothers felt ready to receive an education. Education included follow-up of uterus involution and bleeding, perineum care, breastfeeding, drug use, postpartum risk symptoms, emergencies that require hospital admission, and contraception. Neonatal care education primarily included taking the baby on the lap, umbilical cord care, diaper change, baby bath, dressing the baby, and emergency hospital admissions. Furthermore, mothers were given a manual that was developed by the researchers. The manual, in addition to the above-mentioned issues, included postpartum physical and psychological changes, general hygiene, sleep and rest, time to begin intercourse, nutrition, newborn characteristics, screening programs, vaccination schedule, and contact addresses of health institutions and organizations that can be urgently referred.
The education plan and the manual were prepared according to the topics proposed by the Turkish Ministry of Health for pregnant patients (20). Before the pilot study, expert opinion and approval of four academics, midwives, and nurses were obtained. Education was supported by a demonstration using breast model, doll, bathtub, diapers, etc. materials. Patient rooms are not suitable for education, thus a room was reserved in the clinic to provide comfort for mothers and babies and use for education purposes.

\section{Data Collection}

The data of the control group were first collected to prevent interaction of the experimental and control groups. In the control group, pre-interview was made with mothers giving vaginal birth who are interviewed $6 \mathrm{~h}$ postpartum and mothers giving $\mathrm{C}$-section interviewed $24 \mathrm{~h}$ post-operation. Participants were informed about the aim of the study before obtaining their consent and filling out the personal information form. Then, they filled out the RHD-NMF and PSCS before hospital discharge based on their statements. After the forms were filled, each mother was given an educational manual aside from the "postpartum and neonatal care education." However, no data were collected from this group regarding education.

A similar procedure took place for the data collected from the experimental group. After the personal information form was filled, postpartum and neonatal care education was given to mothers at a time when they felt ready and education manuals were distributed. Finally, they filled the RHD-NMF and PSCS based on their statements before hospital discharge. A pre-administration on 12 postpartum mothers was applied before the study. The study took its final shape based on the results. Cases that are included in the pre-administration were excluded.

\section{Statistical Analyses}

The statistical analyses were made using Statistical Package for the Social Sciences version 24.0. Data were analyzed using the chi-square test, and the adaptation of the scale scores to normal distribution was examined using the Kolmogorov-Smirnov test, Shapiro-Wilk test, and QQ plot graphic. The scale scores showed normal distribution, thus the groups were compared using an independent sample t-test. The correlations between RHD-NMF and PSCS scores were analyzed using the Pearson test. The significance level was found as $p$-values of $<0.05$. The study was approved by the Ethics Committee of Eastern Mediterranean University (ETK00-2019-0113, date: 26.04.2019). Additionally, the consent form following the Declaration of Helsinki was obtained from all participants. 


\section{RESULTS}

The socio-demographic and obstetric characteristics of the groups are shown in Table 1. No difference was found in the socio-demographic and obstetric characteristics of the groups ( $p>0.05)$.

Table 2 shows the mothers' comparison of mean scores from the scales. The analyses indicated that the experimental group's PSCS and RHD-NMF total score and the scores from personal status, knowledge, and ability subscales were higher compared to the control group $(p<0.05)$. However, the mothers' scores in the control group from the RHD-NMF expected support subscale were higher than those of the experimental group $(p<0.05)$.

Table 3 shows the correlation analysis findings between the mothers' RHD-NMF and PSCS scores. Regardless of the experimental or control group, a positive significant correlation was found between the scores of mothers from the overall RHD-NMF, personal status, knowledge, and ability subscales, and PSCS scores $(p<0.05)$. Additionally, the intergroup comparison found positive significant correlations between the scores of the experimental group from the overall RHD-NMF and knowledge subscale and the scores from PSCS $(p<0.05)$. As for the control group, positive significant correlations were found between the mothers' scores from overall RHD-NMF, personal status, knowledge, and ability subscales, and PSCS scores $(p<0.05)$.

\section{DISCUSSION}

The groups have similarities in socio-demographic and obstetric characteristics ( $p>0.05$, Table 1). However, the readiness level of mothers in the experimental group who received an education was higher than those who did not receive education $(p<0.05$, Table 2$)$. Similar studies that investigated the pregnancy and/or postpartum education or information showed that RHD-NMF total scale scores of the groups that receive education were higher than those who did not receive education (21,27,31-34). Another study showed no significant difference between the RHD-NMF total scale scores of mothers who received and who did not receive education; however, a significant difference was found between their RHD-NMF mean scores according to education subjects (35). Based on the samples from the literature and our study results, the postpartum period and discharge preparation increased the mothers' readiness for hospital discharge.

The statistical analysis showed a significant difference in favor of the experimental group regarding the RHDNMF "personal status" subscale $(p<0.05$, Table 2$)$. This finding supported the results of similar two studies (32-34). Contrarily, another study showed no difference between the groups in the personal status mean score (33). Samples from the literature and findings of this study indicated that postpartum and baby-care education increased mothers' physical welfare and readiness to return home after delivery. The scores of the groups from RHD-NMF "Knowledge" and "Ability" subscales were compared and a statistical difference was found in favor of the experimental group $(p<0.05$, Table 2). Similar studies revealed that the mean scores of mothers in the education group from the knowledge and ability subscales were higher than those who did not receive education (32-34). Literature samples and our study results indicated that postpartum and babycare education increased mothers' knowledge level and thus, their ability perception on the matter as intended.

Unlike other subscales and total scale scores, the "expected support" mean score was significantly higher in the control group ( $p<0.05$, Table 2). Findings from similar studies differed from those obtained subscale results (32-34).

This study assessed the effects of postpartum and babycare education on maternal self-confidence using PSCS and showed a significant difference in favor of the experimental group regarding mean score from the scale $(p<0.05 /$ Table 2). Similar studies found that the PSCS total mean score of mothers who received an education was higher compared to those who did not (24-26). Samples from the literature and our study results revealed that postpartum education is efficient in increasing maternal self-confidence.

The correlation between RHD-NMF and PSCS mean score was also analyzed in this study. As the mothers' scores from the overall RHD-NMF increased, the scores that are obtained from PSCS also increased $(p<0.05$, Table 3$)$. This finding showed a positive correlation between the mothers' readiness for early hospital discharge and parental self-confidence. Therefore, postpartum and baby-care education, as in this study, can increase mothers' readiness for hospital discharge, thus their self-confidence in providing baby-care.

\section{CONCLUSION}

The postpartum and baby-care education provided to primipara postpartum mothers before hospital discharge increased the readiness level for hospital discharge and the scores of maternal self-confidence. Furthermore, a positive correlation was found between the two scales. Thus, the offered education possibly prepares the mothers for discharge and supports parental self-confidence. 
Table 1. Comparison of mothers' socio-demographic and obstetric characteristics

\begin{tabular}{|c|c|c|c|c|c|c|c|c|}
\hline & \multicolumn{2}{|c|}{$\begin{array}{l}\text { Experimental group } \\
(n=50)\end{array}$} & \multicolumn{2}{|c|}{$\begin{array}{l}\text { Control group } \\
(n=52)\end{array}$} & \multicolumn{2}{|c|}{$\begin{array}{l}\text { Total } \\
(n=102)\end{array}$} & \multirow[t]{2}{*}{$x^{2}$} & \multirow[t]{2}{*}{$\mathrm{p}$-value } \\
\hline & $\mathrm{n}$ & $\%$ & $\mathbf{n}$ & $\%$ & $\mathbf{n}$ & $\%$ & & \\
\hline Age & \multicolumn{2}{|c|}{$24.42 \pm 5.82$} & \multicolumn{2}{|c|}{$24.63 \pm 4.77$} & \multicolumn{2}{|c|}{$24.52 \pm 5.28$} & & \\
\hline 21 years of age and below & 19 & 38.00 & 14 & 26.92 & 33 & 32.35 & \multirow{3}{*}{1.784} & \multirow{3}{*}{0.410} \\
\hline $22-28$ years of age & 24 & 48.00 & 27 & 51.92 & 51 & 50.00 & & \\
\hline 29 years of age and above & 7 & 14.00 & 11 & 21.15 & 18 & 17.65 & & \\
\hline \multicolumn{9}{|l|}{ Educational status } \\
\hline Primary school & 3 & 6.00 & 4 & 7.69 & 7 & 6.86 & \multirow{4}{*}{0.225} & \multirow{4}{*}{0.974} \\
\hline Secondary school & 20 & 40.00 & 19 & 36.54 & 39 & 38.24 & & \\
\hline High school & 20 & 40.00 & 22 & 42.31 & 42 & 41.18 & & \\
\hline University or higher & 7 & 14.00 & 7 & 13.46 & 14 & 13.73 & & \\
\hline \multicolumn{9}{|l|}{ Employment status } \\
\hline Employed & 18 & 36.00 & 23 & 44.23 & 41 & 40.20 & \multirow{2}{*}{0.718} & \multirow{2}{*}{0.397} \\
\hline Unemployed & 32 & 64.00 & 29 & 55.77 & 61 & 59.80 & & \\
\hline \multicolumn{9}{|l|}{ Family type } \\
\hline Extended family & 9 & 18.00 & 7 & 13.46 & 16 & 15.69 & \multirow{2}{*}{ *1.37 } & \multirow{2}{*}{0.518} \\
\hline Nuclear family & 41 & 82.00 & 45 & 86.54 & 86 & 84.31 & & \\
\hline \multicolumn{9}{|l|}{ Income status } \\
\hline Less income than expense & 20 & 40.00 & 13 & 25.00 & 33 & 32.35 & \multirow{2}{*}{$\star 3.38$} & \multirow{2}{*}{0.184} \\
\hline Equal income and expense & 30 & 60.00 & 39 & 75.00 & 69 & 67.65 & & \\
\hline \multicolumn{9}{|l|}{ Health insurance } \\
\hline Yes & 49 & 98.00 & 49 & 94.23 & 98 & 96.08 & \multirow{2}{*}{-} & \\
\hline No & 1 & 2.00 & 3 & 5.77 & 4 & 3.92 & & \\
\hline \multicolumn{9}{|l|}{ Number of pregnancy } \\
\hline Once & 46 & 92.00 & 46 & 88.46 & 92 & 90.20 & & \\
\hline Two or more & 4 & 8.00 & 6 & 11.54 & 10 & 9.8 & . & \\
\hline Number of abortion & & & & & & & & \\
\hline None & 50 & 100.0 & 48 & 92.31 & 98 & 96.08 & & \\
\hline One or more & 0 & 0.00 & 5 & 9.61 & 5 & 4.9 & & \\
\hline Planning pregnancy & & & & & & & & \\
\hline Planned pregnancy & 45 & 90.00 & 49 & 94.23 & 94 & 92.16 & & \\
\hline Unplanned pregnancy & 5 & 10.00 & 3 & 5.77 & 8 & 7.84 & & \\
\hline Receiving prenatal care & & & & & & & & \\
\hline Yes & 49 & 98.00 & 52 & 100.0 & 101 & 99.02 & & \\
\hline No & 1 & 2.00 & 0 & 0.00 & 1 & 0.98 & & \\
\hline Number of prenatal care & & & & & & & & \\
\hline 9 and below & 16 & 32.00 & 24 & 46.15 & 40 & 39.22 & & \\
\hline Between 10 and 15 & 22 & 44.00 & 13 & 25.00 & 35 & 34.31 & 4,444 & 0.108 \\
\hline 16 and above & 11 & 22.00 & 15 & 28.85 & 26 & 25.49 & & \\
\hline
\end{tabular}


Table 2. Comparison of mothers' scores from readiness for hospital discharge scale-new mother form (RHD-NMF) and Pharis selfconfidence scale (PSCS)

\begin{tabular}{|c|c|c|c|c|c|c|}
\hline & Group & $\mathrm{n}$ & $\chi$ & s & ${ }^{*} t$ & p-values \\
\hline \multirow{2}{*}{$\begin{array}{l}\text { Personal } \\
\text { status }\end{array}$} & Experiment & 50 & 59.52 & 12.02 & \multirow{2}{*}{6,476} & \multirow{2}{*}{$0.000^{\star \star}$} \\
\hline & Control & 52 & 44.52 & 11.38 & & \\
\hline \multirow{2}{*}{ Information } & Experiment & 50 & 58.84 & 7.48 & \multirow{2}{*}{16,476} & \multirow{2}{*}{$0.000^{\star \star}$} \\
\hline & Control & 52 & 27.02 & 11.52 & & \\
\hline \multirow{2}{*}{ Ability } & Experiment & 50 & 25.26 & 3.81 & \multirow{2}{*}{6,840} & \multirow{2}{*}{0.000 ** } \\
\hline & Control & 52 & 20.02 & 3.93 & & \\
\hline \multirow{2}{*}{$\begin{array}{l}\text { Expected } \\
\text { support }\end{array}$} & Experiment & 50 & 14.62 & 7.70 & \multirow{2}{*}{$-2,243$} & \multirow{2}{*}{$0.027^{\star \star}$} \\
\hline & Control & 52 & 17.85 & 6.82 & & \\
\hline \multirow{3}{*}{$\begin{array}{l}\text { RHD-NMF } \\
\text { Total }\end{array}$} & Experiment & 50 & 158.24 & 20.92 & \multirow{2}{*}{10,959} & \multirow{2}{*}{$0.000^{\star \star}$} \\
\hline & Control & 52 & 109.40 & 23.92 & & \\
\hline & Group & $\mathrm{n}$ & & s & $Z^{*}$ & $\mathrm{p}$ \\
\hline \multirow{2}{*}{$\begin{array}{l}\text { Pharis Self-Confidence } \\
\text { Scale }\end{array}$} & Experiment & 50 & 60.30 & 4.33 & \multirow{2}{*}{18,335} & \multirow{2}{*}{$0.000 * \star$} \\
\hline & Control & 52 & 37.50 & 7.70 & & \\
\hline
\end{tabular}

*Unpaired t-test was used, ** $p<0.05$, RHD-NMF: Readiness for hospital discharge scale-new mother form

Table 3. Correlation between the mothers' scores from the readiness for hospital discharge scale-new mother (RHD-NMF) and Pharis self-confidence scale (PSCS)

\begin{tabular}{|c|c|c|c|c|}
\hline \multirow{2}{*}{ Experiment } & & \multicolumn{3}{|c|}{ Pharis Self-confidence scale } \\
\hline & & Control & Total & \\
\hline \multirow{2}{*}{ Personal status } & $r^{*}$ & 0.172 & 0.294 & 0.573 \\
\hline & $\mathrm{p}$ & 0.233 & $0.034^{\star \star}$ & $0.000^{\star *}$ \\
\hline \multirow{2}{*}{ Information } & $r^{*}$ & 0.461 & 0.545 & 0.880 \\
\hline & $\mathrm{p}$ & $0.001^{\star \star}$ & $0.000 * *$ & $0.000^{\star *}$ \\
\hline \multirow{2}{*}{ Ability } & $r^{\star}$ & 0.105 & 0.299 & 0.584 \\
\hline & $p$ & 0.467 & $0.032^{\star \star}$ & $0.000^{\star *}$ \\
\hline \multirow{2}{*}{ Expected support } & $r^{\star}$ & 0.175 & -0.100 & -0.190 \\
\hline & $\mathrm{p}$ & 0.223 & 0.480 & 0.055 \\
\hline \multirow{2}{*}{$\begin{array}{l}\text { Readiness for } \\
\text { discharge }\end{array}$} & $r^{\star}$ & 0.347 & 0.423 & 0.774 \\
\hline & $\mathrm{p}$ & $0.014^{\star \star}$ & $0.002^{\star *}$ & $0.000^{\star *}$ \\
\hline
\end{tabular}

\section{ACKNOWLEDGMENTS}

This study was generated from a postgraduate thesis that was completed at the Eastern Mediterranean University. Additionally, the authors would like to thank all the study participants and the staff in the gynecological diseases and delivery clinic.

\section{ETHICS}

Ethics Committee Approval: The study was approved by the Ethics Committee of Eastern Mediterranean University (ETK00-2019-0113, date: 26.04.2019).
Informed Consent: Participants were informed about the aim of the study before obtaining their consent and filling out the personal information form.

\section{Authorship Contributions}

Surgical and Medical Practices: B.S., Concept: B.S., R.M., Design: B.S., R.M., Data Collection or Processing: B.S., Analysis or Interpretation: B.S., R.M., Literature Search: B.S., R.M., Writing: B.S., R.M.

Conflict of Interest: No conflict of interest was declared by the authors.

Financial Disclosure: The authors declared that this study received no financial support.

\section{REFERENCES}

1. Fahey JO, Shenassa E. Understanding and meeting the needs of women in the postpartum period: The perinatal maternal health promotion model. J Midwifery Womens Health 2013;58:613-21.

2. Martínez-Galiano JM, Hernández-Martínez A, Rodríguez-Almagro J, Delgado-Rodríguez M, Rubio-Alvarez A, Gómez-Salgado J. Women's quality of life at 6 weeks postpartum: Influence of the discomfort present in the puerperium. Int J Environ Res Public Health 2019;16:1-9.

3. Gölbaşı Z. Early Postpartum Discharge Home Care Services and Nursing. Cumhuriyet Nursing Journal 2003;7:15-22.

4. Verpe H, Kjellevold M, Moe V, Smith L, Vannebo UT, Stormark $\mathrm{KM}$, et al. Early postpartum discharge: maternal depression, breastfeeding habits and different follow-up strategies. Scand J Caring Sci 2019;33:85-92.

5. Yonemoto N, Dowswell T, Nagai S, Mori R. Schedules for home visits in the early postpartum period. Cochrane Database Syst Rev 2017:CD009326. 
6. Tiruneh GT, Shiferaw CB, Worku A. Effectiveness and costeffectiveness of home-based postpartum care on neonatal mortality and exclusive breastfeeding practice in low-and-middleincome countries: a systematic review and meta-analysis. BMC Pregnancy Childbirth 2019;19:507.

7. Pallangyo TE, Mbekenga C, Olsson P, Eriksson L, Bergström A. Implementation of a facilitation intervention to improve postpartum care in a low-resource suburb of Dar es Salaam, Tanzania. Implement Sci 2018;13:102.

8. de Montigny F, Lacharite $C$. Fathers' perceptions of the immediate postpartal period. J Obstet Gynecol Neonatal Nurs 2004;33:32839.

9. Ramchandani P, Stein A, Evans J, O'Connor TG; ALSPAC study team. Paternal depression in the postnatal period and child development: a prospective population study. Lancet 2005;365:2201-5.

10. Fasanghari $M$, Kordi $M$, Asgharipour N. Effect of maternal role training program based on Mercer theory on maternal selfconfidence of primiparous women with unplanned pregnancy. J Educ Health Promot 2019;8:1-8.

11. Jones TL, Prinz RJ. Potential roles of parental self-efficacy in parent and child adjustment: A review. Clin Psychol Rev 2005;25:341-63.

12. Reece SM, Harkless G. Self-efficacy, stress, and parental adaptation: Applications to the care of childbearing families. J Fam Nurs 1998;4:198-215.

13. Finlayson K, Crossland N, Bonet M, Downe S. What matters to women in the postnatal period: A meta-synthesis of qualitative studies. PLoS One 2020;15:e0231415.

14. Hammes T, Sebold LF, Kempfer SS, Girondi JBR. Nursing care in postpartum adaptation: perceptions of Brazilian mothers. Journal of Nursing Education and Practice 2014;4:125-33.

15. Leahy-Warren P, McCarthy G, Corcoran P. Postnatal depression in first-time mothers: Prevalence and relationships between functional and structural social support at 6 and 12 weeks postpartum. Arch Psychiatr Nurs 2011;25:174-84.

16. Slomian J, Honvo G, Emonts $P$, Reginster JY, Bruyère $O$. Consequences of maternal postpartum depression: A systematic review of maternal and infant outcomes. Womens Health (Lond) 2019;15. https:// doi: 10.1177/1745506519844044.

17. Bora Güneş, N. Anxiety and Depression Levels of Mothers who have Premature Babies. Hacettepe University. Graduated School of Health Sciences, Pediatric Nursing Program, Doctoral Thesis; 2018.

18. Tan A, Pelone F, Arnold S, Anderson J, Kennedy G, Goodman J. Support and information needs of parents and carers of preterm babies requiring respiratory support on the neonatal unit: $A$ qualitative systematic review. J Neonatal Nurs 2020;26:93-100.

19. Dol J, Campbell-Yeo M, Tomblin Murphy G, Aston M, McMillan D, Gahagan J, et al. Parent-targeted postnatal educational interventions in low and middle-income countries: A scoping review and critical analysis. Int J Nurs Stud 2019;94:60-73.

20. Republic ofTurkey Ministry of Health. Post-partum care management guide. Available from: https://khgmsaglikhizmetleridb.saglik.gov.
tr/TR,42925/dogum-sonu-bakimyonetim-rehberi. Accesssion date: 12.11.2019.

21. Burucu R, Akın B. Effect of Education Administered to Pregnants in Third Trimester on Level of Readiness for Postpartum Discharge. Journal of Hacettepe University Facultiy of Nursing 2017;4:25-35.

22. Kaya Şenol D, Aydın Özkan S, Hotun Şahin N. An investigation of postpartum mothers' readiness for hospital discharge and the affecting factors. Journal of Human Sciences 2017;14:1484-91.

23. Maldonado GM, Connelly CD, Bush RA. Predictors of readiness for hospital discharge after birth: Building evidence for practice. Worldviews Evid Based Nurs 2017;14:118-27.

24. Öztürk S, Erci B. The effect of training provided the primiparas in the postpartum period for motherhood and neonatal care on maternal self-confidence. Gümüşhane University Journal of Health Sciences 2016;5:25-31.

25. Balaban E. The effect of training of mothers of premature infants in neonatal intensive care unit on mother's self-confidence. Marmara University Health Sciences Institute Master Thesis 2016.

26. Batman D. Şeker S. Effect of web based education which has been applied to parents of premature infants to anxiety and selfconfidence. DEUHFED 2019;2:107-15.

27. Akın B, Şahingeri M. Validity and Reliability of Turkish Version of Readiness for Hospital Discharge Scale-New Mother Form (RHDNMF). Journal of Anatolia Nursing and Health Sciences 2010;13:714.

28. Çalışır $\mathrm{H}$. The examination of the factors that affect the maternal role attainment of first-time mothers. Doctoral Thesis. Ege University Health Sciences Institute; 2003.

29. Weiss ME, Ryan P, Lokken L. Validity andrelialibility of the perceived readiness for discharge after birth scale. J Obstet Gynecol Neonatal Nurs 2006;35:34-45.

30. Weiss ME, Piacentine LB. Psychometric properties of the readiness for hospital discharge scale. J Nurs Meas 2006;14:163-80.

31. Altuntuğ K, Ege E. Effects of health education on mothers' readiness for postpartum discharge from hospital, on postpartum complaints, and quality of life. Hemşirelikte Araştırma Geliştirme Dergisi 2013;15:45-56.

32. Dağ H, Dönmez S, Şen E, Şirin A. Postpartum discharge readiness situation of women who had vaginal deliveries. Eur J Ther 2013;19:65-70.

33. Güleç T, Çoban A. The effect of discharging of cesarean postpartum discharge training on the readiness of the mothers to the discharge. J Health Sci Res 2019;6:461-9.

34. Şanar PS, Demirci H. Evolvotion of the planned education programme given to the mothers of the puerpera school named "Healty generations by the concious mothers". J Biotechnol and Strategic Health Res 2018;2:174-81.

35. Türkmen H. Özbaşaran F. Examination of status of readiness for hospital discharge among puerperant women who gave vaginal delivery. Journal of Duzce University Health Sciences Institute 2017;7:24-9. 